\title{
STUDY OF ENTEROCOCCI DURING CHEESE MANUFACTURE AND RIPENING AND EVALUATION OF THEIR ROLE IN TYRAMINE PRODUCTION
}

\author{
R. Burdychová
}

Received: June 12, 2009

\begin{abstract}
BURDYCHOVÁ, R.: Study of enterococci during cheese manufacture and ripening and evaluation of their role in tyramine production. Acta univ. agric. et silvic. Mendel. Brun., 2009, LVII, No. 5, pp. 49-56

The aim of this study was isolation, identification and characterization of bacteria of the genus Enterococcus from Duch-type semi-hard cheese during manufacture and ripening. Cheese samples from two different producers (I and II) were used at the production day and after 30, 90 and 176 days of ripening.

Altogether 361 suspected enterococci isolates were obtained from cheese samples during 7 month of ripening. Using genus-specific PCR, 285 isolates were identified as the members of the genus Enterococcus. The identification of five Enterococcus species was performed by PCR using species-specific primers. Among 165 Enterococcus spp. isolates of producer I, 81 isolates were classified as E. faecium, 39 as E.durans, 21 as E. faecalis, 19 as E. casseliflavus and 3 as E. hirae, and 2 isolates were not classified into species. Enterococci species among isolates of producer II were as follows: 52 isolates of E. faecium, 38 of E. faecalis, 14 of E.durans, 12 of E.casseliflavus, 3 of E. hirae and 1 was not classified into species. E. faecium was found to be the dominating species in all cheese samples. The gene coding for tyrosine decarboxylase was detected in 10 enterococci isolates of producer I and in 5 enterococci isolates of producer II. Production of biogenic amine tyramine was confirmed in all these isolates, which were of $E$. faecium, E. faecalis and E. durans species. It was confirmed that these species are important for tyramine production. There is the relationship between tyramine production and counts of E. faecium, E. faecalis and E.durans. No tyramine production was observed in isolates of E. casseliflavus or E. hirae species.
\end{abstract}

semi-hard cheese, Enterococcus, genus and species-specific PCR, tyrosine decarboxylase gene, tyramine

Enterococci in milk and cheese usually indicate poor bacteriological quality and poor hygiene during manufacture. The source of enterococci is thought to be contaminated water, milking equipment, bulk storage tanks or the faeces of dairy cows (GELSOMINO et al., 2001). The natural habitat of enterococci is the mammalian intestinal tract (FRANZ et al., 1999).

Enterococci have become important over the past decade because they are frequently encountered human pathogens and appear to have increasing antimicrobial resistance (NOSKIN, 1997). The presence of enterococci in pasteurised milk and cheeses has been monitored because they are responsible for many nosocomial infections. Moreover, many en- terococci produce biogenic amines in food (mostly tyramine and histamine), are resistant to glycopeptides and other antibiotics and are able to transfer different genes (mostly antibiotic resistance genes) to other, mostly pathogenic bacteria. On the other hand, several studies have indicated that some strains of enterococci may have a positive influence on the production and ripenning of cheeses, probably through proteolysis, lipolysis, and citrate breakdown, hence contributing to their typical taste and flavour (LITOPOULOU-TZANETAKI et al., 1992; LEDDA et al., 1994).

Many enterococci withstand pasteurisation (most of them resist the temperature of $63{ }^{\circ} \mathrm{C}$ for $30 \mathrm{~min}$ ) which explains their presence in cheeses produced 
from pasteurized milk. Their occurence in cheeses can also be caused by the post-pasteurisation environmental contamination. Levels of enterococci in cheeses depend on the extent of milk contamination, the cheese type, the production season and the starter culture used. Also technology applied, affects their survival and growth under particular conditions of cheese manufacture and ripening (LITOPOLOU-TZANETAKI et al., 1992)

Enterococci play important role in biogenic amines production in fermented foods (KOMPRDA et al., 2007; BURDYCHOVA and KOMPRDA 2007). The aim of this study was monitoring of their species-specific role during cheese manufacture and in tyramine production. Therefore, the main objective was isolation of bacteria of the genus Enterococcus from cheese samples of two different producers during seven months of ripening and identify them to the species level using five species-specific PCRs. Furthermore, screening of isolates for their ability to produce biogenic amine tyramine and determination of relationship between tyramine production and counts of different enterococci species were also objectives of this work.

\section{MATERIALS AND METHODS}

\section{Control bacterial strains and growth conditions}

Control reference strains E. faecium CCM 7250, E. durans CCM 5612, E. hirae CCM 7264 and E. casseliflavus CCM 2478 were obtained from Czech Collection of Microorganisms (CCM, Brno, Czech Republic). The tyramine producing strain Enterococcus faecalis CNRZ 238 was obtained from Deutsche Sammlung von Mikroorganismen und Zellkulturen (DSM, Braunschweig, Germany). All reference strains were grown on Canamycine Aesculin Azide agar (CAA, Merck, Germany) at $37^{\circ} \mathrm{C}$. DNA isolated from these bacteria was used as positive control in PCR analyses.

\section{Cheese manufacture and ripening}

Nine blocks of cheese weigting approximately $13 \mathrm{~kg}$ were produced in each of two dairies; each block was vacuum-packed in a polyethylene casing and let to ripen in the ripening chamber at $10^{\circ} \mathrm{C}$. Three cheese blocks from each producer were taken at the production day (day 0 ) and consequently after 26 and 176 days of ripening.

\section{Determination of tyramine concentration in cheeses}

Tyramine concentration was measured as described by KOMPRDA et al. (2005).

\section{Isolation of enterococci from cheese}

Isolation of enterococci from cheese samples was performed as follows: duplicate $10 \mathrm{~g}$ samples were poured with $90 \mathrm{ml}$ of $45^{\circ} \mathrm{C}$ sterile Ringer solution (Merck, Germany) and shaked in a stomacher (Biotech, USA) for 2 min; decimal dilutions of samples were prepared and plated on Canamycine Aesculine Azide agar (CAA, Merck, Germany) and cultivated for $48 \mathrm{~h}$ at $37^{\circ} \mathrm{C}$. The colonies selected from CAA agar were further isolated into pure cultures by repeated streaking on the same medium. A total of 261 presumptive enterococci, 115 from producer I and 146 from producer II, were used for further identification.

\section{Isolation of DNA and genus - and species - specific PCR}

Standard DNA manipulations were carried out as described by SAMBROOK et al. (2001) and AUSUBEL et al. (1994). The quality of DNA was checked using gel electrophoresis on agarose and by UV spectrophotometry. Identification to the genus level was carried out using El/E2 primer pair (733 bp PCR product) targeted to $16 \mathrm{~S}$ rDNA sequences and according to DEASY et al. (2000); Enterococcus isolates were further identified using five different species-specific PCR-based methods (Table I). PCR assays with primers targeted to D-alanine: D-alanine ligase $(d d l)$ genes were used for identification of En-

I: PCR assays for identification of the genus Enterococcus and Enterococcus species

\begin{tabular}{|c|c|c|c|c|}
\hline Control DNA of strain & Primers & Primer sequences & $\begin{array}{l}\text { PCR product } \\
\text { size (bp) }\end{array}$ & References \\
\hline E. faecium CCM 7250 & $\begin{array}{l}\mathrm{F}_{1} \\
\mathrm{~F}_{2}\end{array}$ & $\begin{array}{l}\text { TAGAGACATTGAATATGCC } \\
\text { TCGAATGTGCTACAATC }\end{array}$ & 550 & $\begin{array}{l}\text { Dutka-Malen et al., } \\
1994\end{array}$ \\
\hline E. durans CCM 5612 & $\begin{array}{l}\text { DuHiF } \\
\text { DuR }\end{array}$ & $\begin{array}{l}\text { TTATGTCCCWGTWTTGAAAAATCAA } \\
\text { TGAATCATATTGGTATGCAGTCCG }\end{array}$ & 186 & Knijff et al., 2001 \\
\hline E. hirae CCM 7264 & $\begin{array}{l}\text { DuHiF/ } \\
\text { HiR }\end{array}$ & $\begin{array}{l}\text { TTATGTCCCWGTWTTGAAAAATCAA } \\
\text { TTT TGT TAG ACC TCT TCC GGA }\end{array}$ & 377 & Knijff et al., 2001 \\
\hline E. casseliflavus CCM 2478 & $\begin{array}{l}\text { CA1 } \\
\text { CA2 }\end{array}$ & $\begin{array}{l}\text { TCCTGAATTAGGTGAAAAAAC } \\
\text { GCTAGTTTACCGTCTTTAACG }\end{array}$ & 288 & Jackson et al., 2004 \\
\hline Enterococcus faecalis CNRZ 238 & $\begin{array}{l}E_{1} \\
E_{2}\end{array}$ & $\begin{array}{l}\text { ATCAAGTACAGTTAGTCTT } \\
\text { ACGATTCAAAGCTAACTG }\end{array}$ & 941 & $\begin{array}{l}\text { Dutka-Malen et al., } \\
1994\end{array}$ \\
\hline $\begin{array}{l}\text { E. faecium CCM } 7250 \text { genus } \\
\text { Enterococcus }\end{array}$ & $\begin{array}{l}E_{1} \\
E_{2}\end{array}$ & $\begin{array}{l}\text { TCAACCGGGGAGGGT } \\
\text { ATTACTAGCGATTCCGG }\end{array}$ & 733 & Deasy et al., 2000 \\
\hline
\end{tabular}


terococcus isolates to the species level. PCR products are specific for E. faecalis (941 bp), E. faecium (550 bp), E. hirae (377 bp) and E. durans (186 bp). Identification of E. casseliflavus was based on amplification of specific DNA sequence for manganese-dependent superoxide dismutase $(\operatorname{sod} A)$. The primers used, the supposed length of amplicons and reference to literature which describes amplification conditions used are shown in Table I (DUTKA-MALEN et al., 1995; KNIJFF et al., 2001; JACKSON et al., 2004).

PCR from one bacterial colony was also used for the identification of enterococci. PCR reactions were performed in a total volume of $25 \mu \mathrm{l}$, containing $1 \mu \mathrm{l}$ of each primer $(10 \mathrm{pmol} / \mu \mathrm{l}), 12.5 \mu \mathrm{l}$ of Qiagen HotStar Master Mix (Qiagen, Hilden, Germany) and one bacterial colony. In positive controls, $1 \mu \mathrm{l}(10 \mathrm{ng} / \mu \mathrm{l})$ of DNA isolated from each control strain was used.

PCRs were carried out using model PTC-150HB thermal cycler (MJ Research, Waltham, MA, USA). Amplicons were visualized in UV light after electrophoresis in $1 \%$ agarose gel $(5 \mathrm{~V} / \mathrm{cm})$ in $0,5 \times \mathrm{TBE}$ buffer after ethidium bromide staining $(0,5 \mu \mathrm{g} / \mathrm{ml})$. The documentation was carried out with CD34 Polaroid kamera on TT667 film.

\section{Screening of enterococci isolates for their ability to produce tyramine}

Cultivation in decarboxylating medium (BOVERCID and HOLZAPFEL 1999), HPLC described by BURDYCHOVA and DOHNAL (2007), and PCR detection of genes coding enzymes tyrosindecarboxylase (COTON et al., 2004) were used as the screening methods. Bacterial strain E. faecium CNRZ 238, tyramine producer described in the study of COTON et al. (2004), was used as positive control for the PCR. PCR was carried out as desribed by BURDYCHOVA and KOMPRDA (2007). Out of 285 entrococci isolates were examined by the methods mentioned above.

\section{RESULTS}

Isolated enterococci were first identified into genus level. PCR analysis of suspected 285 enterococci isolated from cheese samples resulted in PCR product of expected lenght (733 bp) only in 261 cases. So, 261 isolates were identified to the genus Enterococcus.

Out of 261 Enterococcus spp. strains, 111 (45 \%) isolates were proved to be E. faecium, 70 (29\%) as E. durans, $30(12 \%)$ as E. faecalis, 24 (10\%) as E. casseliflavus and $4(2 \%)$ as E. hirae. However, 3 enterococci strains (1\%) could not be identified into no studied species by the methods used. Agarose gel electrophoresis of PCR products used for identification of enterococci species using PCR shows Fig. 1.

Distribution of enterococci in cheese samples of both producers during ripening is shown in Table II and Fig. 2. Enterococci counts in the cheeses samples from producer I were higher in comparison with those of producer II. At any rate, enterococci contamination of the cheeses from producer I at the begin of ripening, presumably from an ambient environment of the dairy I, follows from Table II.

Because tyramine was described as the most common biogenic amine in ripening cheeses (STRATTON et al., 1991) in toxicologically relevant levels ( $\geq 100 \mathrm{mg} / \mathrm{kg}$ ), further experiments were focused on screening of enterococci isolates for their ability to produce tyramine. Cultivation in decarboxylating medium (BOVER-CID and HOLZAPFEL, 1999), HPLC descibed by BURDYCHOVA and DOHNAL (2007), and PCR detection of genes coding enzymes tyrosindecarboxylase and histidindecarboxylase, participating in formation of biogenic amines (COTON et al., 2004) were used as the screening methods. Altogether, the tyramine production was detected at 15 enterococci isolates, the most of strains (246) were negative for ability to produce tyramine. 10 tyramine producing enterococci isolates originated from cheese samples of producer 1, 5 from those of producer II. The most tyramine producers were of E. durans species. Distribution of tyramine producing enterococci species among cheese samples of two producers shows Table II. To study if the counts of tyramine producing enterococci influence tyramine content in cheeses, the concentration of tyramine in cheeses was examined using HPLC (data not shown).

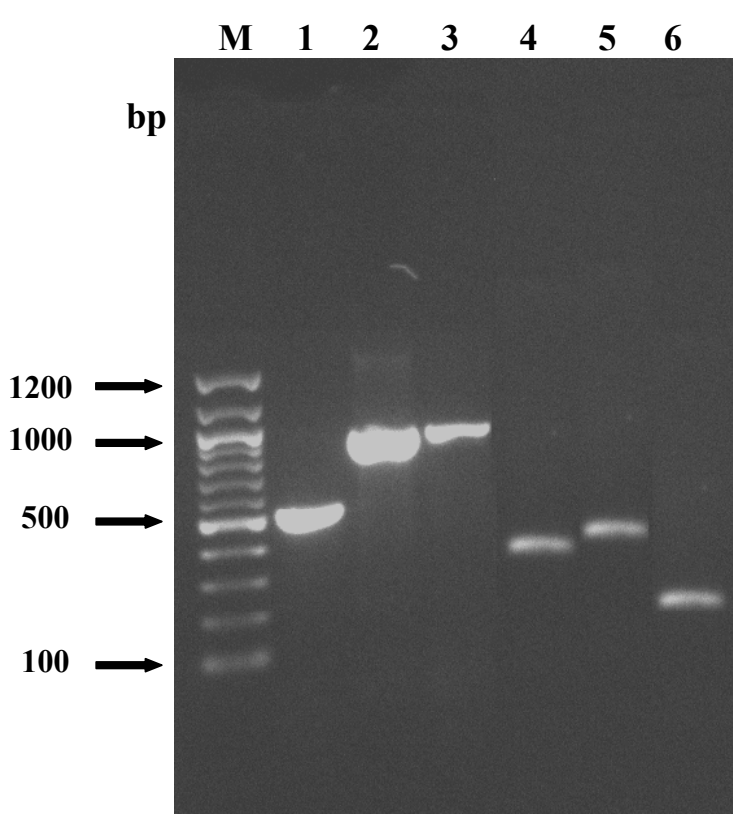

M: 100 bp ladder (New England Biolabs, England), lane 1: E. faecium (550 bp), lane 2: E. faecalis (941 bp), lane 3: E. faecalis (941 bp), lane 4: E. hirae (377bp), lane 5: E. casseliflavus (439 bp), lane 6: E. durans (186 bp)

1: PCR identification of bacteria of the genus Enterococcus isolated from semi-hard cheese 
II: Percentage composition of enterococci in cheese samples of 2 producers during ripening and presence of enterococci strains producing tyramine

\begin{tabular}{|c|c|c|c|c|c|c|c|c|}
\hline & \multirow{2}{*}{$\begin{array}{c}\text { Cheese samples } \\
\text { (days of } \\
\text { ripening) }\end{array}$} & \multicolumn{6}{|c|}{ Species composition } & \multirow{2}{*}{ Total } \\
\hline & & E. faecium & E. faecalis & E. durans & E. casseliflavus & E. hirae & unidentified & \\
\hline \multirow{6}{*}{$\begin{array}{l}\text { Producer 1 } \\
\text { (165 } \\
\text { isolates) }\end{array}$} & 0 & 23 & 8 & 15 & 7 & 2 & 1 & 56 \\
\hline & 30 & 24 & 6 & 10 & 5 & - & - & 45 \\
\hline & 90 & 15 & 3 & 7 & 3 & 1 & - & 29 \\
\hline & 176 & 19 & 4 & 7 & 4 & - & 1 & 35 \\
\hline & total & 81 & 21 & 39 & 19 & 3 & 2 & \\
\hline & $\begin{array}{l}\text { tyramine } \\
\text { producer }\end{array}$ & 16 & 2 & 7 & - & - & - & 25 \\
\hline \multirow{6}{*}{$\begin{array}{l}\text { Producer } 2 \\
\text { (120 } \\
\text { isolates) }\end{array}$} & 0 & 14 & 10 & 6 & 4 & 1 & - & 35 \\
\hline & 30 & 14 & 11 & 3 & 4 & 1 & 1 & 34 \\
\hline & 90 & 8 & 7 & 2 & 2 & 1 & - & 20 \\
\hline & 176 & 16 & 10 & 3 & 2 & - & - & 31 \\
\hline & total & 52 & 38 & 14 & 12 & 3 & 1 & \\
\hline & $\begin{array}{l}\text { tyramine } \\
\text { producer }\end{array}$ & 7 & 1 & 1 & - & - & - & 9 \\
\hline
\end{tabular}
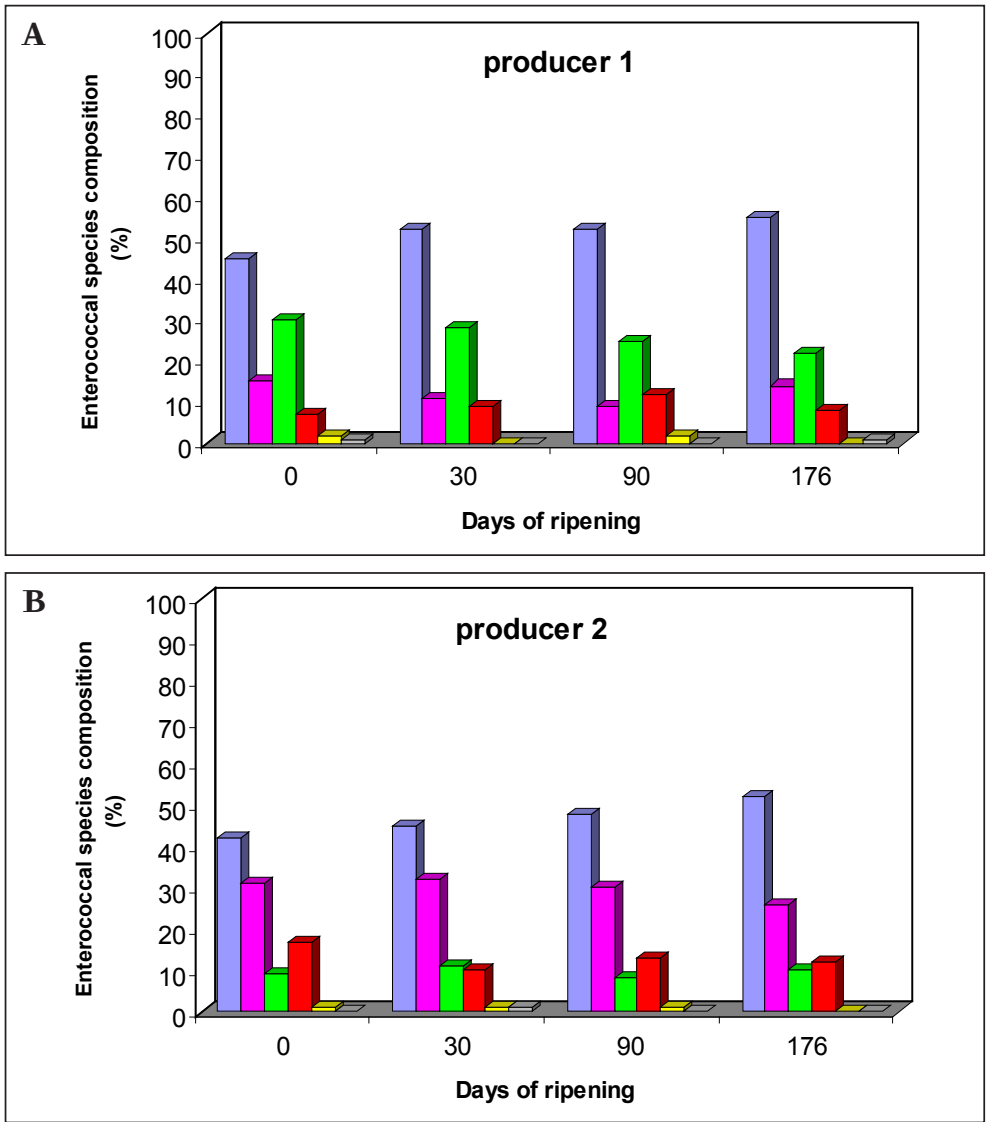

2: Percentage composition of enterococci in semihard cheese during 176 days of ripening. Each group represents a total number of isolates from each producer (A 165 isolates; B 120 isolates). Total number of enterococcal species in cheese samples at 0, 30, 90 and 176 days of ripening represents $100 \%(P<0,05)$. $\square$. faecium, $\square$ E. faecalis, $\square$ E.durans, $\square$ E. casseliflavus, $\square$ E. hirae, $\square$ unidentified. 


\section{DISCUSSION}

Enterococci occur and grow in raw milk, pasteurized milk and milk products. The main reasons for this prevalence in milk products have been considered to poor hygienic conditions during collection and processing of milk. Other factors can account for the predominance of enterococci such as their resistance to high temperatures, their adaptability to different substrates and wide range of habitats (WESSELS et al., 1990; LITOPOULOU-TTZANETAKI, 1992; SUZZI et al., 2000). On the other hand, it is well known (MORENO et al., 2002) that enterococci can positively contribute to the flavour development during cheese ripening. Moreover, they can also produce several enzymes that interact with milk components, thus promoting important biochemical transformations.

The use of 165 and 235 rDNA sequences as a method of bacterial classification is well established (LANE et al., 1989; BOTTGER, 1989; SALAMA et al., 1991). These sequences contain universally conserved regions and regions unique to particular genera or species. To date, 28 species of the genus Enterococcus were identified. E. faecalis and E. faecium represent ca. $90 \%$ of food and clinical isolates belonging to this genus. Because also E. $d u$ rans, E. hirae and E. casseliflavus occurs in milk and milk products and are described as causative agents of different types of infections (DUTKA-MALEN et al., 1995; KNIJFF et al., 2001; JACKSON et al., 2004), the presence of these 5 species was chosen for screening of Enterococcus species in cheese samples of two producers during 7 month of rippening. The milk for cheese production came from different milk suppliers and therefore cheeses were made in different hygienic conditions. The higher amount of enterococci in cheese samples from producer I can be caused either by contamination of raw milk (from the udder, teats surface, or bulk tank) or by secondary contamination of milk after pasteurization and during cheese manufacture (cheese-making equipment, milker, aerial contamination, milking equipment contamination from residual water after wasching of equipment). E. faecium and E. durans were found to be the dominating species in all cheese samples from producer I, E. faecium and E. faecalis dominated in enterococcal microflora of cheese samples from producer II. These results are in agreement with another studies (ARIZCUN et al., 1997, COGAN et al., 1997, DEVRIESE et al., 1995, SUZZI et al., 2000) where the most common species in cheese were E. faecium and E. faecalis or E. faecium and E.durans. In our study, the numbers of E. faecalis were very low in cheese samples of producer I. This indicates good hygienic conditions during milking process, manipulation and cheese manufacture, because E. faecalis is considered to be the most common species in human feeces (FACKLAM and COLLINS, 1989) and was often found in dairy cows (DEVRIESE et al., 1992).
E. durans was the second dominant species isolated from all cheese samples of producer I. E. $d u$ rans (and E. hirae) are infrequently isolated from humans. In domestic animals, E. durans also appears to be a relatively rare inhabitant of the gut, except in preruminant calves. Furthermore, the above mentioned species are being found in foods of animal origin and in water (DEVRIESE et al., 1992). MCAULEY et al. (2005) described E. durans isolates from raw milk which survived pasteuration. Our results show that E. durans grew in cheese. It is possible that E. durans originated from residual water after wasching of cheese-making equipment or it survived the pasteurization of milk. This is in agreement with the study of FRANC et al. (1999) who showed that the most frequently isolated Enterococcus species from milk and cheese are E. faecium, E. faecalis and E.durans.

The smallest counts in both cheese sample sets were of E. casseliflavus. This disagrees with the study of GELSOMINO et al. (2002), where E. casseliflavus dominated among the isolates of human faeces, milk and cheese. The autors supposed that the main contamination reservoir was milking equipment. It follows from our results that regarding the whole enterococci counts, both producers operated in good hygienic conditions including effectivity of sterilization and disinfection.

The distribution of tyramine producing enterococci in cheese samples of both producers is shown in Table II. Majority of tyramine producing isolates came from cheese samples of producer I, the most frequent tyramine producing Enterococcus species was E. faecium, followed by E. durans and E. faecalis. It follows from our experiments that in cheese samples with higher enterococci counts having ability to produce tyramine were higher levels of biogenic amine tyramine. An expected higher amount of tyramine in cheese samples of producer I in comparison with producer II was confirmed by comparison of tyramine content in particular cheese samples during ripening. The amount of tyramine in cheese of producer I was approximately four times higher $(70 \mathrm{mg} / \mathrm{kg})$ than in cheese from producer II and exceeded the tyramine toxic level $(100 \mathrm{mg} / \mathrm{kg}$ ) when ripened more than 120 days. The presence of enterococci in Duch-type cheesse and their influence on tyramine production was discussed earlier by BURDYCHOVA and KOMPRDA (2007). Strict observance of proper hygiene conditions during cheese manufacture and ripening is recommended for the reduction of enterococci counts. Generally we can say that long-term ripening and storage of these types of cheesse support accumulation of tyramine. Therefore they are not recommended for consummation, mainly by persons with tyramine intolerance which is very much connected with migraines and cluster headaches. 


\section{SUMMARY}

Enterococci in milk and cheese usually indicate poor bacteriological quality and poor hygiene during manufacture. The source of enterococci is thought to be contaminated water, milking equipment, bulk storage tanks or the faeces of dairy cows (GELSOMINO et al., 2001). The natural habitat of enterococci is the mammalian intestinal tract (FRANZ et al., 1999).

Many enterococci withstand pasteurisation (most of them resist the temperature of $63{ }^{\circ} \mathrm{C}$ for $30 \mathrm{~min}$ ) which explains their presence in cheeses produced from pasteurized milk. Their occurence in cheeses can also be caused by the post-pasteurisation environmental contamination (LITOPOLOUTZANETAKI et al., 1992).

Enterococci play important role in biogenic amines production in fermented foods (KOMPRDA et al., 2007; BURDYCHOVA and KOMPRDA, 2007). The aim of this study was monitoring of their speciesspecific role during cheese manufacture and in tyramine production. Therefore, the main objective was isolation of bacteria of the genus Enterococcus from cheese samples of two different producers during seven months of ripening and identify them to the species level using five species-specific PCRs. Furthermore, screening of isolates for their ability to produce biogenic amine tyramine using PCR described by COTON et al. (2004) and BURDYCHOVA and DOHNAL (2007) and determination of relationship between tyramine production and counts of different enterococci species were also objectives of this work. Cheese samples from two different producers (I and II) were used at the production day and after 30, 90 and 176 days of ripening.

Altogether 361 suspected enterococci isolates were obtained from cheese samples during 7 month of ripening. Using genus-specific PCR, 285 isolates were identified as the members of the genus Enterococcus. The identification of five Enterococcus species was performed by PCR using species-specific primers. Among 165 Enterococcus spp. isolates of producer I, 81 isolates were classified as E. faecium, 39 as E.durans, 21 as E. faecalis, 19 as E. casseliflavus and 3 as E. hirde, and 2 isolates were not classified into species. Enterococci species among isolates of producer II were as follows: 52 isolates of E. faecium, 38 of E. faecalis, 14 of E.durans, 12 of E.casseliflavus, 3 of E. hirae and 1 was not classified into species. E. faecium was found to be the dominating species in all cheese samples. The gene coding for tyrosine decarboxylase was detected in 10 enterococci isolates of producer I and in 5 enterococci isolates of producer II. Production of biogenic amine tyramine was confirmed in all these isolates, which were of $E$. faecium, E. faecalis and E. durans species.

It follows from our experiments that in cheese samples with higher enterococci counts having ability to produce tyramine were higher levels of biogenic amine tyramine. An expected higher amount of tyramine in cheese samples of producer I in comparison with producer II was confirmed by comparison of tyramine content in particular cheese samples during ripening. The amount of tyramine in cheese of producer I was approximately four times higher $(70 \mathrm{mg} / \mathrm{kg})$ than in cheese from producer II and exceeded the tyramine toxic level $(100 \mathrm{mg} / \mathrm{kg})$ when ripened more than 120 days.

The presence of enterococci in Duch-type cheesse and their influence on tyramine production was discussed earlier by BURDYCHOVA and KOMPRDA (2007). Strict observance of proper hygiene conditions during cheese manufacture and ripening is recommended for the reduction of enterococci counts. Generally we can say that long-term ripening and storage of these types of cheesse support accumulation of tyramine. Therefore they are not recommended for consummation, mainly by persons with tyramine intolerance which is very much connected with migraines and cluster headaches.

\section{SOUHRN}

Studium enterokoků a jejich role v produkci tyraminu během výroby a zrání polotvrdých sýrů

Enterokoky se vyskytují jako přirozená součást zažívacího traktu většiny savců a ptáků (FRANZ et al., 1999). Výskyt enterokoků v mléku a sýrech bývá často spojován s nedostatečnou hygienickou kvalitou výroby. Jako kontaminanty se do těchto potravin dostávají převážně vlivem nedostačujících hygienických podmínek v průběhu výroby sýrů a mohou působit negativně na tvorbu aromatických složek. Zdrojem jsou nejčastěji kravské fekálie, kontaminovaná voda, vybavení mlékárenského podniku nebo tanky pro skladování mléka (GELSOMINO et al., 2001). Některé kmeny přežívají pasterační teploty, proto jsou běžnou součástí mikroflóry pasterovaného mléka (LITOPOLOU-TZANETAKI et al., 1992). Enterokoky hrají důležitou roli při tvorbě biogenních aminů ve fermentovaných potravinách (KOMPRDA et al., 2007; BURDYCHOVA and KOMPRDA 2007). Cílem této práce bylo sledování vlivu enterokoků na produkci biogenního aminu tyraminu během zrání eidamských sýrů. Analyzovány byly vzorky sýrů pocházející od dvou výrobců (výrobce I a II). Analýzy byly provedeny v den výroby a 30, 90 a 180 dní po výrobě.

Ze sýrů byly izolovány bakterie rodu Enterococcus, které byly dále identifikovány a charakterizovány pomocí rodově a druhově specifických PCR. Identifikované izoláty byly prověřeny na schopnost tvo- 
řit biogenní amin tyramin pomocí PCR popsané COTONEM a kol. (2004) a pomocí HPLC popsané BURDYCHOVOU a DOHNALEM (2007). Cílem práce bylo dále určit souvislost mezi počtem enterokoků a množstvím tyraminu v sýrech.

Během šesti měsíců zrání polotvrdých sýrů bylo izolováno celkem 361 presumptivních enterokoků, 285 izolátů bylo pomocí rodově specifické PCR zařazeno k rodu Enterococcus. Druhová identifikace izolátů byla provedena pomocí druhově specifických PCR. Ze 165 izolátů, které pocházely ze vzorků sýrů výrobce I, bylo 81 zařazeno ke druhu E. faecium, 39 ke druhu E. durans, 21 ke druhu E. faecalis, 19 ke druhu E. casseliflavus a tři ke druhu E. hirae. Dva izoláty nebyly použitými metodami identifikovány. Izoláty pocházející ze vzorků sýrů výrobce II byly identifikovány takto: 52 izolátů bylo zařazeno ke druhu E. faecium, 38 ke druhu E. faecalis, 14 ke druhu E. durans, 12 ke druhu E. casseliflavus, tř̀ ke druhu E. hirae; jeden izolát nebyl použitými metodami identifikován.

Sekvence kódující tyrosindekarboxylázu byla detekována u deseti enterokoků izolovaných ze sýrů výrobce I a pěti enterokoků izolovaných ze sýrů výrobce II. Produkce biogenního aminu tyraminu byla prokázána u všech těchto izolátů. Izoláty byly identifikovány jako zástupci druhů E. faecium, E. faecalis a E.durans. Bylo prokázáno, že existuje souvislost mezi počty těchto druhů a tvorbou tyraminu při zrání polotvrdých sýrů.

Z výsledků této práce vyplývá, že v sýrech s vyšším počtem enterokoků s prokázanou schopností tvořit tyramin byl stanoven vyšší obsah tyraminu. Očekávaná vyšší koncentrace tyraminu v sýrech výrobce I (v porovnání se sýry výrobce II) byla potvrzena porovnáním obsahu tyraminu v jednotlivých sýrech. Množství tyraminu v sýrech výrobce I bylo přibližně čtyřikrát vyšší (70 mg/kg) než v sýrech výrobce II. Množství tyraminu v sýrech výrobce I dokonce po 120 dnech zrání přesáhlo toxikologický limit (100 mg/kg).

Výskyt a role enterokoků v polotvrdých sýrech byla již dříve diskutována BURDYCHOVOU a KOMPRDOU (2007). Pro redukci počtu enterokoků a redukci koncentrace tyraminu v polotvrdých sýrech je doporučováno striktní dodržení správných hygienických podmínek během výroby sýrů. Obecně lze říci, že je dlouhá perioda zrání sýrů podporuje tvorbu biogenních aminů. Z tohoto důvodu nejsou dlouhozrající sýry doporučovány pro pravidelnou konzumaci ve větších množstvích, zejména ne osobám často trpícím bolestmi hlavy a migrénami.

polotvrdé sýry, Enterococcus, rodově a druhově specifická PCR, gen pro tyrosindekarboxylázu, tyra$\min$

We thank Assoc. Professor Alena Spanova for helpful discussions and assistance in preparing the manuscript. Special thanks to Pavla Sladkova for technical assistance. This work was partially supported by grant no. 2102/IG260271 from Mendel University of Agriculture and Forestry in Brno.

\section{REFERENCES}

ARIZCUN, C., BARCINA, Y., TORRE, P., 1997: Identification and characterization of proteolytic activity of Enterococcus ssp. isolated from milk and Runcal and Idiazabal cheese. Int. J. Food Microbiol., 38: 17-24.

AUSUBEL, F. M., BRENT, R., KINGSTON, R. E., MOORE, D. D., SEIDMAN, J. G., SMITH, J. A., STRUHL, K., 1994: Current protocols in molecular biology. New York, Greene Publishing Associates and Wiley-Interscience.

BOTTGER, E. C., 1989: Rapid determination of bacterial ribosomal RNA sequences by direkt sequencing of enzymatically amplified DNA. FEMS Microbiol Lett., 65: 171-176.

BOVER-CID, S., HOLZAPFEL, W. H., 1999: Improved screening procedure for biogenic amine production by lactic acid bacteria. International Journal of Food Microbiology., 53: 33-41.

BURDYCHOVA, R., DOHNAL, V., 2007: The use of HPLC method for determination of microbial tyrosine decarboxylase expression product. Chemickélisty, 101: 907-910.
BURDYCHOVA, R., KOMPRDA, T., 2007: Biogenic amine forming microbial communities in cheese. FEMS Microbiol Lett., 276, 149-155.

COGAN, T. M., BARBOSA, M., BEUVIER, E., BIANCHI-SALVADORIS, B., COCCONCELLI, P. S. FERNANDES, I., GOMEZ, J., GOMEZ, R., KALANTZOPOULOS, G., LEDDA, A., MEDINA, M., REA, M. C., RODRIGUEZ, E., 1997: Characterization of the lactic acid bacteria in artisanal dairy products. J. Dairy Res., 64: 409-421.

COTON, M., COTON, E., LUCAS, P., LONVAUD, A., 2004: Identification of the gene encoding a putative tyroxine decarboxylase of Carnobacterium divergens 508. Development of molecular tools for the detection of tyramine-producing bacteria. Food Microbiol., 21: 125-130.

DEASY, B. M., REA, M. C., FITZGERALD, G. F., COGAN, T. M., BERESFORD, T. P., 2000: A rapid PCR based method to distinguish between Lactococcus and Enterococcus. System. Appl. Microbiol., 23: 510-522.

DEVRIESE, L. A., LAURIER, L., DE HERDT, P., HAESEBROUCK, F., 1992: Enterococcal and streptococcal species isolated from faeces of calves, 
young cattle and dairy cows. J. Appl. Bacteriol., 72: 29-31.

DEVRIESE, L. A., POT, B., VAN DAMME, L., KERSTERS, K., HAESEBROUCK, F., 1995: Identification of Enterococcus species isolated from foods of animal origin. Int. J. Food Microbiol., 26: 187-197.

DUTKA-MALEN, S., AVERS, S., COURVALIN, P., 1995: Detection of glycopeptide resistance genotypes and identification to the species level of clinically relevant Enterococci by PCR. J. Clin. Microbiol., 1: 24-27.

FACKLAM, R. R., COLLINS, M. D., 1989: Identification of Enterococcus species isolated from human infections by a conventional test scheme. J. Clin. Microbiol., 27: 3340-3343.

FRANZ, C. M., HOLZAPFEL, W. H., STILES, M. E., 1999: Enterococci at the crossroads of food safety. Int. J. Food Microbiol., 47: 1-24.

GELSOMINO,R., VANCANNEYT,M., CONDON, S., SWINGS, J., COGAN, T. M., 2001: Enterococcal diversity in the environment of an Irish Cheddartype cheesemaking factory. Int. J. Food Microbiol., 71: 177-188.

GELSOMINO, R., VANCANNEYT, M., COGAN, T. M., CONDON, S., SWINGS, J., 2002: Source of enterococci in a farmhouse raw-milk cheese. Applied and environmental Microbiology, 68: 3560-3565.

JACKSON, CH. R., FEDORKA-CRAY, P. J., BARRETT, J. B., 2004: Use of a Genus- and Species-Specific Multiplex PCR for Identification of Enterococci. J. Clin. Microbiol., 42 (8): 3558-3565.

KNIJFF, E., DELLAGLIO, F., LOMBARDI, A., ANDRIGHETTO, C., TORRIANI, S., 2001: Rapid identification of Enterococcus hirae by PCR with primers targeted to the $d d l$ genes. J. Microbiol. Methods., 47: 35-40.

KOMPRDA, T., NOVICKÁ, K., KALHOTKA, L., SMĚLÁ, D., 2005: Biogenic amine content in sterilised and pasteurised long-term stored processed cheese. Czech Journal of Food Sciences. 23 (5): 209-216.

KOMPRDA, T., BURDYCHOVA, R., DOHNAL, V., CWIKOVA, O., SLADKOVA, P., 2008: Some factors influencing biogenic amines and polyamines content in Dutch-type semi-hard cheese. Eur Food Res Technol, 227:29-36
LANE, D. J., PACE, B., OLSEN, G. J., STAHL, D. A., SOGIN, M. L., PACE, N. R., 1989: Rapid determination of $16 \mathrm{~S}$ ribosomal RNA sequences for phylogenetic analyses. Proc. Natl. Acad. Sci., 82: 6955-6956.

LEDDA, A., SFINGU, M. F., PARISI, A., SANNA, S., MANNU, L., 1994: Technologial characterization of lactococci and enterococci for the manufacture of Fiore Sardo scheep cheese. Scienza e Tecnica Lattiero-Casearia., 45: 443-456.

LITOPOULOU-TZANETAKI, E., TZANETAKIS, N., 1992: Microbiology of white brined cheese made from raw goat milk. Food microbiol., 9: 13-19.

MCAULEY, C., GOBIUS, K., BRITZ, M., CRAVEN, H., 2005: Heat resistance of Enterococcus durans and E. hirae isolated from pasteurised milk. $2^{\text {nd }}$ International ASM-FEMS conference on Enterococci. Helsingor, Denmark.

NOSKIN, G. A., 1997: Vancomycin-resistant enterococci: clinical, microbiologic and epidemiologic features. J. Lab. Clin. Med., 130: 14-20.

MORENO, M. R. F., LEISNER, J. J., TEE, L. K., RADU, S., RUSUL, G., VANCANNEYT, M., DE VUYST, L., 2002: Microbial analysis of Malaysian tempeh and characterization of two bacteriocinss produced by isolats of Enterococcus faecium. J Appl Microbiol., 92: 147-57.

SALAMA, M., SANDINE, W., GIOVANNONI, S., 1991: Development and application of oligonucleotide probes for identification of Lactococcus lactis supsp. cremoris. Appl. Environ. Microbiol., 57: 1313-1318.

SAMBROOK, J., FRITSCH, E. F., MANIATIS, T., 1989: Molecular Cloning: a Laboratory Manual. Cold Spring Harbor Laboratory Press, New York, USA.

STRATTON, J. E., HUTKINS, R. V., TAYLOR, S. L., 1991: Biogenic amines in cheese and other fermented foods. A review. J. Food Prot., 54: 460-470.

SUZZI, G., CARUSO, M., GARDINI, F., LOMBARDI, A., VANNINI, L., GUERZONI, M. E., ANDRIGHETTO, C., LANORTE, M. T., 2000: A survey of the enterococci isolated from an artisanal Italian goat's cheese (semicotto caprino). J. Appl. Microbiol., 89: 267-274.

WESSELS, D., JOOSTE, P. J., MUSTERT, J. F., 1990: Technologically important characteristics of Enterococcus isolates from milk and dairy products. Int. J. Food Microbiol., 10: 349-352. 